\title{
Pharmacokinetics in patients with chronic liver disease and hepatic safety of incretin-based therapies for the management of type 2 diabetes
}

\author{
André J. Scheen \\ University of Liège, Center for Interdisciplinary Research on Medicines (CIRM), \\ Division of Diabetes, Nutrition and Metabolic Disorders \\ and Division of Clinical Pharmacology, \\ Department of Medicine, CHU Sart Tilman, University of Liège, Liège, Belgium

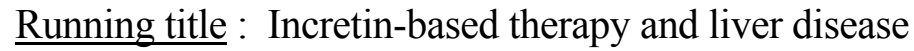

$\underline{\text { Word count }}$ :

Address for correspondence :

Pr André J. SCHEEN

Department of Medicine

CHU Sart Tilman (B35)

B-4000 LIEGE 1

BELGIUM

Phone : 32-4-3667238

FAX : 32-4-3667068

Email : andre.scheen@ chu.ulg.ac.be 


\section{SUMMARY}

Patients with type 2 diabetes have an increased risk of chronic liver disease such as nonalcoholic fatty liver disease and steatohepatitis, and about one third of cirrhotic patients have diabetes. However, the use of several antidiabetic agents, such as metformin and sulphonylureas, may be a concern in case of hepatic impairment (HI). New glucose-lowering agents targeting the incretin system are increasingly used for the management of type 2 diabetes. Incretin-based therapies comprise oral inhibitors of dipeptidyl peptidase-4 (DPP-4) (gliptins) or injectable glucagon-like peptide-1 (GLP-1) receptor agonists. This narrative review summarizes the available data regarding the use of both incretin-based therapies in patients with HI. In contrast to old glucose-lowering agents, they were evaluated in specifically designed acute pharmacokinetic studies in patients with various degrees of $\mathrm{HI}$ and their hepatic safety was carefully analyzed in large clinical trials. Only mild changes in PK characteristics of DPP-4 inhibitors were observed in patients with different degrees of HI, presumably without major clinical relevance. GLP-1 receptor agonists have a renal excretion rather than liver metabolism. Specific PK data in patients with HI are only available for liraglutide. No significant changes in liver enzymes were reported with DPP-4 inhibitors or GLP-1 receptor agonists, alone or in combination with various other glucose-lowering agents, in clinical trials up to 2 years. On the contrary, preliminary data suggested that incretin-based therapies may be beneficial in patients with CLD, more particularly in presence of nonalcoholic fatty liver disease. Nevertheless, caution should be recommended, especially in patients with advanced cirrhosis, because of a lack of clinical experience with incretin-based therapies in these vulnerable patients.

Key-words : Cirrhosis - DPP-4 inhibitor - Gliptin - GLP-1 receptor agonist - Hepatic impairment - Hepatotoxicity - Pharmacokinetics 


\section{Key sentences}

- Following acute administration, PK parameters of all evaluated DPP-4 inhibitors (gliptins) and of liraglutide (the only GLP-1 receptor agonist tested so far) are not or only slightly altered by the presence of mild to severe hepatic impairment.

- Obese patients with type 2 diabetes often have non-alcoholic fatty liver disease or steatohepatitis and the use of incretin-based therapies appears mostly favourable in these patients regarding both efficacy and safety.

- There is no reported clinical experience with the use of either DPP-4 inhibitors or GLP-1 receptor agonists in diabetic patients with moderate to severe hepatic impairment, so that caution is required in patients with advanced cirrhosis. 


\section{Introduction}

The complex bi-directional relationship linking liver and diabetes mellitus has recently gained great interest ${ }^{[1,2]}$. Type 2 diabetes mellitus (T2DM) favours non-alcoholic fatty liver disease (NAFLD), progressing from steatosis to non-alcoholic steatohepatitis, (NASH) and possibly cirrhosis ${ }^{[3]}$, while alcoholic cirrhosis and chronic hepatitis $\mathrm{C}$ virus are frequently associated with glucose metabolism disturbances ${ }^{[4]}$. Diabetes, which frequently develops as a complication of cirrhosis, is known as "hepatogenous diabetes" ${ }^{[5]}$; it has a complex pathophysiology combining both impaired insulin secretion and insulin resistance ${ }^{[6,7]}$. Liver tests are commonly altered in patients with overweight/obesity and in patients with T2DM. While the prevalence of NAFLD ranges $10-24 \%$ in the general population, it may reach 60$95 \%$ and $28-55 \%$ in severely obese and diabetic patients, respectively ${ }^{[8]}$. In this context, it has be hypothesized that NAFLD may be considered as a new target for T2DM prevention and treatment ${ }^{[9]}$.

Managing diabetes in patients with chronic liver disease (CLD) can be challenging because many antihyperglycaemic therapies are contraindicated or must be used with caution for safety reasons ${ }^{[10]}$. A higher risk of lactic acidosis with metformin, of hypoglycaemia with sulphonylureas or hepatotoxicity with the first commercialized thiazolidinedione (troglitazone) has been reported ${ }^{[10]}$. The scarce review papers about the management of diabetic patients with CLD focused on general management rather than on the specific use of glucose-lowering agents ${ }^{[11,12]}$.In this context, the place of new medications, such as incretinbased therapies, was almost not considered, except in recent reviews ${ }^{[13,14]}$.

Incretin-based therapies include either oral agents acting as inhibitors of the dipeptidyl peptidase-4 (DPP-4), also called gliptins, or injectable agents acting as agonists of the glucagon-like peptide-1 (GLP-1) receptors ${ }^{[15]}$. By inhibiting the inactivation of both endogenous glucagon-like peptide-1 (GLP-1) and glucose-dependent insulinotropic polypeptide (GIP), DPP-4 inhibitors stimulate insulin secretion and reduce glucagon secretion, both in a glucose-dependent manner. This dual effect results in a clinically relevant improvement of glucose control without inducing hypoglycaemia or weight gain (in contrast to sulphonylureas) in T2DM patients ${ }^{[16]}$. GLP-1 receptor agonists exert a more marked reduction in hyperglycaemia together with a significant weight loss. These metabolic effects are the result of enhanced glucose-stimulated insulin secretion, inhibition of glucagon release, delayed gastric emptying and increased satiety due to a direct action in the brain. All these 
mechanisms may vary according to the type of GLP-1 receptor agonist used with different effects on fasting and postprandial hyperglycaemia ${ }^{[17,18]}$.

The present review aims at providing an updated analysis of the pharmacokinetic (PK) characteristics of incretin-based therapies, both DPP-4 inhibitors and GLP-1 receptor agonists, in patients with various degrees of hepatic impairment (HI). In addition, the reported clinical experience in diabetic patients with $\mathrm{CLD}^{[19]}$ and the liver safety as assessed in controlled clinical trials will also be briefly summarized for these two pharmacological classes targeting the incretin system. This piece of information should help the physician to decide how to use incretin-based therapies in patients with CLD and to better position this pharmacological class in the overall management of T2DM in clinical practice.

\section{Literature search}

To identify relevant studies in this narrative review, an extensive literature search of MEDLINE (based on titles and abstracts) was performed from January 2005 to July 1st 2014, with the names of DPP-4 inhibitors or GLP-1 receptor agonists combined with any of the following terms : "chronic liver disease", "hepatic impairment" or "cirrhosis". Each generic name - sitagliptin, vildagliptin, saxagliptin, linagliptin, alogliptin for the DPP-4 inhibitors; exenatide, liraglutide, lixisenatide for the GLP-1 receptor agonists - was also combined with each of the various terms corresponding to CLD. No language restrictions were imposed. No a priori specific inclusion or exclusion criteria were imposed during the literature search. Reference lists of original studies, narrative reviews and previous systematic reviews were also carefully examined.

\section{Evaluation of severity of $\mathbf{H I}$}

PK studies are of particular interest in subjects with impaired hepatic function if hepatic metabolism accounts for a substantial portion of the absorbed drug ${ }^{[20]}$. Despite most incretinbased therapies are cleared through the kidney, PK studies with DPP-4 inhibitors and liraglutide were performed in patients with CLD. In clinical pharmacology, the Child-Pugh score is used to quantify the severity of $\mathrm{HI}$ in order to guide the use of drugs in patients with CLD, although the limitations of this approach have been acknowledged ${ }^{[20]}$. HI is generally classified into three levels of severity using the Child-Pugh scores : mild HI (class A $=$ scores 5-6), moderate HI (class B = scores 7-9) and severe HI (class C : scores 10-15). Such classification has been used in the various PK studies described below. 
Besides HI itself, renal function should also be considered in diabetic patients with CLD. Indeed, hepatorenal syndrome is a distinctive complication of CLD and cirrhosis ${ }^{[21]}$. Therefore, renal function should be carefully monitored in all patients with cirrhosis and selection of antidiabetic pharmacotherapy should also take into account the possibility of associated renal impairment in such patients ${ }^{[22]}$. This is of major importance because the dosage of DPP-4 inhibitors (except linagliptin) should be adjusted to the glomerular filtration rate and there are restrictions regarding the use of GLP-1 receptor agonists in presence of moderate to severe kidney insufficiency ${ }^{[14,22]}$.

\section{DPP-4 inhibitors}

Several molecules are already available, which are characterized by different PK properties $^{[23,24]}$. The PK characteristics of the five DPP-4 inhibitors already on the market worldwide - sitagliptin, vildagliptin (except in the US), saxagliptin, linagliptin and alogliptin were studied in patients with various degrees of HI (Table 1).

\subsection{Sitagliptin}

\section{Pharmacokinetics}

The influence of moderate HI on the PK of sitagliptin should be minimal. Indeed, sitagliptin is primarily excreted by renal elimination as unchanged drug, with only a small percentage (approximately 16\%) undergoing hepatic metabolism. CYP3A4 is the major cytochrome P450 isoenzyme responsible for the limited oxidative metabolism of sitagliptin, with some minor contribution from $\mathrm{CYP} 2 \mathrm{C} 8^{[25]}$. In an open-label study, a single 100-mg oral dose of sitagliptin was administered to patients with moderate CLD (Child-Pugh's scores ranged from 7 to 9) and healthy subjects used as controls ${ }^{[26]}$. The mean area under plasma concentration-time curve from zero to infinity $\left(\mathrm{AUC}_{\infty}\right)$ and maximum plasma concentration $\left(\mathrm{C}_{\max }\right)$ for sitagliptin were numerically higher in patients with moderate $\mathrm{HI}$ compared with healthy matched control subjects (Table 1). These slight differences were not considered to be clinically meaningful. Furthermore, moderate HI had no statistically significant effect on the $\mathrm{T}_{\max }$, apparent terminal half-life $\left(\mathrm{t}_{1 / 2}\right)$ and renal clearance of sitagliptin. Thus, moderate $\mathrm{HI}$ has no clinically meaningful effect on the PK of sitagliptin in this acute study ${ }^{[26]}$. However, no study has been performed in patients with more severe HI neither after chronic administration of the drug. 


\section{Hepatic safety}

The efficacy of sitagliptin therapy has been shown in patients with T2DM complicated by NAFLD ${ }^{[27-30]}$ NASH $^{[31]}$ or CLD caused by hepatitis $\mathrm{C}$ virus ${ }^{[32]}$. However, one report suggested that NAFLD may adversely affect the glycaemic control obtained with $\operatorname{sitagliptin}^{[33]}$.

In a systematic review and meta-analysis about the longer term safety of DPP-4 inhibitors in patients with T2DM, hepatotoxiticy was not considered as a concern ${ }^{[34]}$. No hepatotoxicity of sitagliptin has been shown in a pooled analysis of 25 clinical studies (Table 2). Nevertheless, a few cases of drug-induced hepatic injury associated with sitagliptin ${ }^{[35]}$ or of elevated hepatic enzymes potentially associated with sitagliptin ${ }^{[36]}$ have been reported. The causal relationship remains, however, uncertain because of the complex medical history of many case reports ${ }^{[37]}$.

\subsection{Vildagliptin}

\section{Pharmacokinetics}

Vildagliptin is primarily metabolized via hydrolysis and the inactive metabolites are predominantly excreted by the kidneys ${ }^{[38]}$. An open-label, parallel-group study compared the PK of vildagliptin in patients with mild, moderate or severe CLD and in healthy control subjects. All subjects received a single 100-mg oral dose of vildagliptin, and plasma concentrations of vildagliptin were measured up to $36 \mathrm{~h}$ post-dose ${ }^{[39]}$. $\mathrm{AUC}_{\infty}, \mathrm{C}_{\max }$ and other PK parameters were only minimally and not significantly influenced by the presence of mild, moderate or severe HI (Table 1). Because of this absence of changes in exposure to vildagliptin in patients with mild, moderate or severe HI, the conclusion was that no dose adjustment of vildagliptin is necessary in patients with $\mathrm{CLD}^{[39]}$.

\section{Hepatic safety}

There was initial concern about a possible hepatotoxicity of vildagliptin so that liver safety was particularly checked with this compound. No increase of liver enzymes has been shown in a pooled analysis of 38 controlled trials with vildagliptin (Table 2). For mild hepatic enzyme elevations with and without elevated bilirubin levels, the odds ratio for vildagliptin 50 mg bid were 1.24 (95\% confidence interval or CI: [0.80, 1.93]) and 1.19 (95\% CI: [0.29, 
4.90]), respectively. The exposure-adjusted incidences of markedly elevated hepatic enzymes and for enzyme elevations with bilirubin $\geq 2$ times the upper limit of normal with vildagliptin were similar or lower than those in the all comparator group. For all hepatic-related adverse events, the odds ratio for vildagliptin was 0.87 (95\% CI: $[0.64,1.19])^{[40]}$. These data were confirmed in another pooled analysis showing that vildagliptin was overall well tolerated in clinical trials of up to $>2$ years in duration ${ }^{[41]}$.

\subsection{Saxagliptin}

\section{Pharmacokinetics}

In contrast with other DPP-4 inhibitors, saxagliptin is metabolized in vivo to form an active metabolite, 5-hydroxy saxagliptin (2-fold less potent than its parent molecule). Both parent drug and metabolite are excreted primarily via the kidneys ${ }^{[24]}$. Saxagliptin is largely metabolized by CYP3A4 and CYP3A5 isoforms. The PK of saxagliptin and its pharmacologically active metabolite were compared in nondiabetic subjects with mild, moderate or severe CLD and in healthy adult subjects in an open-label, parallel-group, singledose (10 mg saxagliptin) study ${ }^{[22,43]}$. As compared with controls, the $\mathrm{AUC}_{\infty}$ values for saxagliptin were $10 \%, 38 \%$ and $77 \%$ higher in subjects with mild, moderate or severe $\mathrm{HI}$, respectively (Table 1). The corresponding values were $22 \%, 7 \%$ and $33 \%$ lower, respectively, for 5-hydroxy saxagliptin, compared with healthy subjects. Saxagliptin $\mathrm{C}_{\max }$ values were $8 \%$ higher, $16 \%$ higher and $6 \%$ lower in patients with mild, moderate and severe HI, respectively, compared to controls (corresponding values for 5-hydroxy saxagliptin : $-17 \%$, $16 \%$ and $-59 \%$, respectively) (Table 1). Thus, the increase of the parent drug saxagliptin exposure appears to be compensated for by a corresponding decrease of the exposure to its active metabolite, 5-hydroxy saxagliptin. Therefore, no dose adjustment of saxagliptin is recommended for diabetic patients with any degree of $\mathrm{HI}^{[43]}$. However, again, caution should be recommended in patients with advanced CLD.

\section{Hepatic safety}

No specific concern about liver safety of saxagliptin has been reported so far ${ }^{[44]}$. In the placebo-controlled SAVOR-TIMI 53 cardiovascular outcome trial (which randomized 16,492 T2DM patients at high cardiovascular risk, followed for a median of 2.1 years), no signal of 
liver toxicity could be detected with saxagliptin $5 \mathrm{mg}$ versus placebo, whatever the biological criterion taken into account (Table 3$)^{[45]}$.

\subsection{Linagliptin}

\section{Pharmacokinetics}

In contrast to other DPP-4 inhibitors whose main route of elimination is the kidney ${ }^{[23,}$ ${ }^{24]}$, the elimination of linagliptin is primarily non-renal ${ }^{[46]}$. Linagliptin undergoes enterohepatic cycling with a large majority $(85 \%)$ of the absorbed dose eliminated in faeces via biliary excretion ${ }^{[24]}$. Given the predominantly non-renal route of elimination, it is particularly important to characterize the PK of linagliptin in patients with $\mathrm{HI}$, in order to clarify potential risks and dosing implications. Consequently, in contrast with other DPP-4 inhibitors, linagliptin was also evaluated in a more sophisticated study testing a multiple dose administration, rather than only a single dose administration, in patients with mild to moderate CLD.

An open label, parallel group, study enrolled patients with mild, moderate or severe CLD and healthy subjects to investigate whether HI affects linagliptin PK, PD and tolerability ${ }^{[47]}$. Primary endpoints were linagliptin exposure following $5 \mathrm{mg}$ linagliptin once daily for 7 days in patients with mild and moderate HI versus healthy subjects. However, in those individuals, PK characteristics were also carefully analyzed after the first oral administration. In addition, such PK data were also obtained in patients with severe HI who only received a single $5 \mathrm{mg}$ dose linagliptin. Data obtained after acute administration are summarized in Table 1. Because of the initial rapid clearance of non-DPP-4 bound drug, $\mathrm{AUC}_{0-24 \mathrm{~h}}$ was considered a more sensitive parameter than $\mathrm{AUC}_{\infty}$ to detect any effect of $\mathrm{HI}$ on linagliptin exposure (beyond $24 \mathrm{~h}$ the PK of linagliptin mainly reflects the binding to DPP-4 enzyme and slow dissociation of the linagliptin/DPP-4 complex). Results showed no trend to increased exposure with more severe HI. Rather $\mathrm{AUC}_{0-24 \mathrm{~h}}$ and $\mathrm{C}_{\max }$ tended to be lower in patients with mild to moderate $\mathrm{HI}$ than in healthy subjects. The inter-individual variability in single dose PK parameters was highest among patients with severe $\mathrm{HI}$. After a single dose, mean $\mathrm{AUC}_{0-24 \mathrm{~h}}$ in patients with severe HI was similar to that in healthy subjects. $\mathrm{C}_{\max }$ tended to be lower, although quite similar to mean values obtained in patients with mild or moderate HI (Table 1). Steady-state PK parameters measured after 7-day linagliptin administration were generally comparable between patients with mild and moderate $\mathrm{HI}$ and healthy subjects, with only a slight trend to 
lower linagliptin exposure (Table 4). The relatively lower linagliptin exposure in patients with HI may appear somewhat surprising and several explanations may be proposed for this observation as discussed by the Authors ${ }^{[47]}$. The most likely reason for the absence of increased exposure to linagliptin despite HI may be related to the PK and PD properties of the drug. Because linagliptin is predominantly eliminated without involvement of hepatic metabolism and because linagliptin has a high DPP-4 enzyme binding capacity, preserved hepato-biliary excretion of predominantly unchanged linagliptin is sufficient. After one week of administration linagliptin $5 \mathrm{mg}$ once daily, accumulation based on AUC or $\mathrm{C}_{\max }$ and renal excretion of unchanged linagliptin $(\leq 7 \%)$ were comparable across groups. Median plasma DPP-4 inhibition was similar in healthy subjects (91\%), and patients with mild (90\%) and moderate (89\%) HI at steady-state trough concentrations, and in patients with severe HI $24 \mathrm{~h}$ after a single dose (84\%). Thus, mild, moderate or severe HI did not result in any increase in linagliptin exposure after single and multiple dosing compared with normal hepatic function, and did not influence the effect of linagliptin $5 \mathrm{mg}$ on DPP-4 inhibition. The conclusion was that dose adjustment with linagliptin is not required in patients with $\mathrm{HI}^{[47]}$.

\section{Hepatic safety}

Reassuring hepatic safety data have also been reported with linagliptin as shown in a meta-analysis of 8 placebo-controlled trials (Table 2$)^{[48]}$. In the only study where a DPP-4 inhibitor (5 mg linagliptin) was administered once daily for 7 days in patients with mild and moderate HI, the DPP-4 inhibitor was well tolerated ${ }^{[47]}$. Only one case report described a probable linagliptin-induced liver toxicity, but again caution is required when interpreting this event $^{[49]}$.

\subsection{Alogliptin}

\section{Pharmacokinetics}

Alogliptin is metabolized into 2 identified minor metabolites: M-I, an N-demethylated active metabolite via CYP2D6, and M-II, an N-acetylated inactive metabolite. CYP3A4 may also be involved in the formation of other unidentified minor metabolites. Exposure to these 2 metabolites in plasma, relative to unchanged drug, are $<1 \%$ and $<6 \%$, respectively, so that 
they are not considered as clinically relevant. Metabolism represents only a small part of the elimination of alogliptin, which is mainly renally excreted ${ }^{[23,24]}$.

After a single oral administration of $25 \mathrm{mg}$ alogliptin, no clinical significant differences in $\mathrm{AUC}$ and $\mathrm{C}_{\max }$ exposure to the parent drug and its active metabolite M1 were observed in subjects with moderate HI (Child-Pugh 7-9) compared with healthy subjects (Table 1) ${ }^{[50]}$.The elimination of both alogliptin and M1 was 2.5 hours longer in patients with moderate HI than in normal subjects. However, the magnitude of these increases was not considered clinically relevant. Therefore, no dose adjustment is necessary for patients with mild to moderate HI (Child-Pugh classes A and B) ${ }^{[50]}$. However, these data were reported only as an abstract so that caution is recommended ${ }^{[51]}$. Moreover, subjects with more severe HI were not evaluated $^{[50]}$.

\section{Hepatic safety}

No hepatoxicity has been reported in the development programme of alogliptin ${ }^{[52]}$. The cardiovascular outcome study EXAMINE recruited 5,380 T2DM patients after an acute coronary syndrome. They were randomly assigned to alogliptin $25 \mathrm{mg}$ once daily $(12.5 \mathrm{mg}$ in case of renal impairment) or placebo. After a median follow-up of 18 months years, no signal of hepatotoxicity was detected in the alogliptin group (Table 3) ${ }^{[53]}$. An observational Japanese study reported that hypoglycaemic symptoms under therapy with alogliptin may be associated with liver disease and alcohol consumption ${ }^{[54]}$.

\section{GLP-1 receptor agonists}

When oral therapy is not sufficient to control blood glucose, injectable agents may be used. Besides insulin therapy, GLP-1 receptor agonists (exenatide, liraglutide, lixisenatide) offer new opportunities for the management of $\mathrm{T}_{2} \mathrm{DM}^{[55]}$. A recent review describes the PK and safety aspects of the currently available GLP-1 receptor agonists ${ }^{[56]}$. However, almost no data are available yet in patients with CLD, except for liraglutide that was evaluated in a specific PK study ${ }^{[57]}$.

\subsection{Exenatide}

\section{Pharmacokinetics}

No PK studies with exenatide, either its original formulation or its long-acting release preparation (once weekly formulation), have been done in patients with CLD. Because 
exenatide is cleared primarily by the kidney, HI is not expected to affect blood levels of this GLP-1 receptor agonist and effects on glucose control in T2DM patients ${ }^{[58]}$.

\section{Hepatic safety}

Exenatide has been shown to improve glucose control in patients with T2DM and concomitant $\mathrm{NAFLD}^{[59-61]}$ or $\mathrm{NASH}^{[62]}$. A recently published animal study suggested that $\mathrm{SIRT}_{1}$, a NAD+-dependent protein deacetylase that is considered as a crucial regulator in hepatic lipid homeostasis, mediates the effect of exenatide on ameliorating hepatic steatosis ${ }^{[63]}$. An interim analysis of data from the open-label, uncontrolled extension of three double-blind, placebo-controlled trials examined the metabolic effects of 2 years of exenatide treatment in patients with T2DM. Patients with normal baseline ALT had no significant ALT change. However, patients with elevated ALT at baseline had a slight but significant reduction of ALT from baseline and 39\% achieved normal ALT by week $104^{[64]}$. This beneficial effect may be explained by the concomitant weight loss and better glucose control with exenatide, two changes that could reduce NAFLD ${ }^{[61]}$. Nevertheless, it should be pointed out that no studies or data exist regarding the use of exenatide in patients with HI.

\subsection{Liraglutide}

\section{Pharmacokinetics}

Liraglutide is metabolized in vitro by DPP-4 and neutral endopeptidase in a manner similar to that of native GLP-1, although at a much slower rate because it is partially resistant to the action of DPP-4. The metabolite profiles suggest that both enzymes are also involved in the in vivo degradation of liraglutide. The lack of intact liraglutide excreted in urine and feces and the low levels of metabolites in plasma indicate that liraglutide is completely degraded within the body ${ }^{[65]}$.

A parallel group, open label trial compared the PK of a single-dose $(0.75 \mathrm{mg}$ injected subcutaneously) of liraglutide in four groups of six subjects with normal liver function, mild, moderate and severe HI, respectively ${ }^{[57]}$. Exposure to liraglutide was not increased by HI (Table 5). On the contrary, mean $\mathrm{AUC}_{\infty}$ was highest for healthy subjects and lowest for subjects with severe HI. $\mathrm{C}_{\max }$ also tended to decrease with $\mathrm{HI}$, while $\mathrm{t}_{\max }$ was similar across groups. Total apparent clearance and apparent volume of distribution tended to increase with the degree of severity of $\mathrm{HI}$; the difference was significant in patients with severe CLF 
compared to subjects with normal liver function. According to the authors, because the halflife of liraglutide was not affected by $\mathrm{HI}$, the differences in the overall exposure $\left(\mathrm{AUC}_{\infty}\right)$ of liraglutide might result primarily from differences in absorption of the drug from the subcutaneous depot rather than differences in its subsequent metabolism. The unbound fraction of liraglutide was very low in all groups, but the observed mean fraction unbound in the group of subjects with severe HI was lower than that in the healthy group. Because the vast majority of liraglutide molecules are reversibly bound to plasma albumin, a decrease in albumin concentration as seen in patients with severe CLD may also result in an increased rate of metabolism of liraglutide by various enzymes. However, this PK effect, resulting in lower plasma levels, might be compensated for by a possible enhanced PD effect. Indeed, in the setting of reduced circulating albumin concentrations, an increased free fraction of liraglutide is able to interact with GLP-1 receptors. Because of these diverse effects, data are not conclusive to suggest a dose increase of liraglutide in presence of HI. Thus, the results indicate that patients with T2DM and CLD can use standard treatment regimens of liraglutide. There is, however, currently limited clinical experience with liraglutide in patients with $\mathrm{HI}^{[57]}$.

\section{Hepatic safety}

Individual patient data meta-analysis of the LEAD program showed that a 26 -week therapy with liraglutide $1.8 \mathrm{mg}$ (maximum recommended dose) is safe, well tolerated and improves liver enzymes in patients with T2DM. As already discussed for exenatide, this effect appears to be mediated by the favourable action of liraglutide on weight loss and glycaemic control $^{[66]}$. Furthermore, a few data support a beneficial impact of liraglutide on liver inflammation markers in NAFLD patients with $\mathrm{T} 2 \mathrm{DM}^{[67]}$, in obese women with polycystic ovary syndrome and NAFLD ${ }^{[68]}$ and in one T2DM patient with concomitant cryptogenic cirrhosis $^{[69]}$. In a recent pilot Japanese study, treatment with liraglutide had a good safety profile and significantly improved liver function and histological features in NASH patients with glucose intolerance ${ }^{[70]}$. A clinical case of suspected liraglutide-induced autoimmune hepatitis has been recently reported ${ }^{[71]}$. Although caution is required when interpreting the causal relationship of such event ${ }^{[37]}$, further postmarketing studies are needed to define the hepatotoxic potential of liraglutide and other GLP-1 receptor agonists.

\subsection{Lixisenatide}

\section{Pharmacokinetics}


The elimination of lixisenatide is expected to follow that of endogenous peptides with renal filtration followed by tubular reabsorption and subsequent metabolic catabolism ${ }^{[72]}$. The influence of HI on lixisenatide PK characteristics has not been evaluated. However, no dose adjustment is needed in patients with CLD as hepatic dysfunction is not expected to affect the PK of lixisenatide ${ }^{[73]}$.

\section{Hepatic safety}

No specific analysis has been performed yet with lixisenatide, but no liver safety concern has been reported with this new GLP-1 receptor agonist ${ }^{[72]}$.

\section{Discussion}

Despite the fact that incretin-based therapies are rather new approaches in the management of $\mathrm{T} 2 \mathrm{DM}^{[15]}$, their $\mathrm{PK}$ characteristics in patients with different degrees of $\mathrm{HI}$ have been more extensively investigated and thereby are better known as compared to older glucose-lowering agents such as metformin and sulphonylureas ${ }^{[10]}$. The PK characteristics of all DPP-4 inhibitors have been assessed in patients with CLD. Whereas vildagliptin ${ }^{[39]}$, saxagliptin $^{[43]}$ and linagliptin ${ }^{[47]}$ have been evaluated after a single oral dose in patients with mild, moderate or severe HI, sitagliptin ${ }^{[26]}$ and alogliptin ${ }^{[50,51]}$ have only been tested in patients with moderate HI, according to Child-Pugh staging. Regarding GLP-1 receptor agonists, only liraglutide has been evaluated in a specifically designed study in patients with mild, moderate and severe $\mathrm{HI}^{[57]}$. Because these injectable peptides are mainly cleared by DPP-4 enzyme and via renal rather than hepatic route, it is understandable that no specific studies have been performed with all GLP-1 receptor agonists ${ }^{[20]}$.

All studies with DPP-4 inhibitors showed only minimal and probably not clinically relevant changes in PK characteristics whatever the degree of severity of HI. Especially, drug exposure, estimated by either AUC or $\mathrm{C}_{\max }$, was not significantly modified. Saxagliptin is the only DPP-4 so far that is metabolized in the liver with the production of an active metabolite, 5-hydroxy-saxagliptin, whose capacity of inhibition of the enzyme DPP-4 is almost half of the parent drug ${ }^{[23,24]}$. Thus, in the PK study performed in patients with various degrees of CLD, the increase of saxagliptin exposure is probably compensated for by a corresponding decrease of the exposure to its active metabolite, suggesting that no dose adjustment is mandatory for patients with any degree of $\mathrm{HI}^{[43]}$. Nevertheless, caution should probably be recommended, at 
least in patients with severe HI.

The results of the PK study performed with liraglutide in CLD patients illustrate the complex condition of some patients with severe HI, including late-stage of cirrhosis. Indeed, in the group with severe HI, lower exposure to liraglutide, possibly related to reduced subcutaneous absorption or increased volume of distribution, may be at least partially compensated for by a lower mean unbound fraction of liraglutide in this group than in the healthy group; this latter effect results from a decreased albumin concentrations secondary to the severe $\mathrm{HI}^{[57]}$. These data suggest that results may vary from patient to patient in this vulnerable group of individuals with severe CLD. Thus, this complex situation requests much caution when using GLP-1 receptor agonists in this population, especially because no information is available so far for exenatide and lixisenatide.

Whereas only minimal PK changes have been reported after an acute administration of the five DPP-4 inhibitors currently available worldwide, no single study evaluated the PK after chronic administration in diabetic patients with CLD. Only linagliptin was evaluated after a 7day short-term administration allowing steady-state plasma levels ${ }^{[47]}$. Even if no significant changes were described in steady-state PK characteristics in patients with mild to moderate CLD, it should be pointed out that patients with severe HI were only investigated after a single dose administration in this study ${ }^{[47]}$. Thus, caution is required, especially in patients with severe HI. In contrast to patients with CLD, in patients with chronic kidney disease, several studies have been published, which combine not only PK analysis after a single administration but also clinical efficacy/safety data after chronic administration up to 1 year in T2DM patients ${ }^{[22]}$. Such long-term clinical studies are not available in diabetic patients with CLD. Finally, it is also important to check regularly kidney function in individuals with advanced CLD, because the rather high prevalence of the hepatorenal syndrome in this population that may impact on the PK characteristics of the incretin-based therapies ${ }^{[21]}$.

Anecdotal case reports raised some concern about a possible hepatotoxicity of DPP-4 inhibitors. However, it is always difficult to confirm a causal relationship in such observational reports because of the presence of many confounding factors ${ }^{[37]}$. Pooled analyses of large clinical trials with sitagliptin ${ }^{[34]}$, vildagliptin ${ }^{[40]}$ and linagliptin ${ }^{[48]}$ (Table 2) as well as data from the two recently published major cardiovascular outcome studies reporting liver safety data with saxagliptin ${ }^{[45]}$ and alogliptin ${ }^{[53]}$ (Table 3) are reassuring. On the contrary, some preliminary data suggested that inhibition of DPP-4 might be beneficial in 
CLD ${ }^{[74,75]}$. The serum DPP-4 activity and the staining intensity of DPP-4 in liver are correlated with histopathologic grade of NASH and hepatosteatosis. Thus, DPP-4 can be proposed as a novel candidate with several potential functions in NASH pathogenesis ${ }^{[74]}$. Another recent paper suggested that DPP-4 may be a key player in CLD, a finding that may open new perspectives for the use of DPP-4 inhibitors in patients with CLD $^{[75]}$. However, no clinical study with a chronic administration of a DPP-4 inhibitor in patients with CLD is available yet. Interestingly, the LEAN ("Liraglutide Efficacy and action in NASH") trial is currently investigating whether a 48 -week treatment with $1.8 \mathrm{mg}$ liraglutide will result in improvements in liver histology in patients with $\mathrm{NASH}^{[76]}$. Another attractive finding in humans showed that glucose-induced GLP-1 secretion is deficient in patients with NAFLD, an observation that paves the route for using incretin-based therapies in these patients ${ }^{[77]}$. However, these data should be confirmed in patients well-matched for BMI because high BMI (present in these patients with NAFLD) is one of the strongest predictors of deficient GLP-1 secretion ${ }^{[78]}$. Finally, in another study, improved glucose control correlated with liver fat reduction in obese T2DM patients given GLP-1 receptor agonists exenatide or liraglutide for 6 months ${ }^{[60]}$. There is growing evidence that incretin-based therapies have beneficial effects on hepatocytes; however, further study analysis are needed to assess the long-term effect of incretin-based therapies on NAFLD ${ }^{[19]}$.

It is important to know the PK/PD characteristics of incretin-based therapies in patients with HI because these glucose-lowering agents are increasingly used in clinical practice and because the number of patients with both diabetes and CLD is increasing too, especially due to the rapidly progressing prevalence/incidence of NAFLD, NASH and cirrhosis associated to obesity and T2DM. Clinical trials in diabetic patients with CLD would be of interest as those that were performed and reported in patients with chronic kidney disease. Furthermore, longterm clinical experience in real life would add a valuable piece of information, even though clinicians should remain cautious when using these drugs in diabetic patients with advanced CLD.

\section{Conclusion}

Old antidiabetic drugs (metformin, sulphonylureas) were poorly investigated in patients with CLD so that their use is classically contraindicated in patients with moderate to severe HI. Detailed PK data have been published specifically in patients with various degrees 
of HI with all five available DPP-4 inhibitors and GLP-1 receptor agonists (only liraglutide so far). Overall, the results were almost reassuring, with only limited PK changes, most probably without clinical relevance. NAFLD and NASH are generally improved by the use of glucoselowering agents such as incretin-based therapies, via a better glucose control especially and possibly some weight loss associated with reduced insulin resistance. However, no long-term studies are available demonstrating both the efficacy and safety of DPP-4 inhibitors or GLP-1 receptor agonists in T2DM patients with mild to severe CLD. Thus, caution is recommended, especially in patients with advanced cirrhosis for whom the problem of controlling effectively and safely blood glucose becomes more crucial and most often requires insulin therapy.

\section{Funding and conflict of interest}

No sources of funding were used to assist in the preparation of this manuscript. No conflicts of interest are directly relevant to the content of this manuscript.

A.J. Scheen has received lecture/advisor fees from AstraZeneca/BMS, Boehringer Ingelheim, Eli Lilly, Merck Sharp \& Dohme, Novartis, NovoNordisk, Sanofi-Aventis and Takeda.

Table 1 : Main PK parameters of DPP-4 inhibitors (single oral dose) in subjects with various degrees of chronic liver disease (CLD) (according to Child-Pugh staging) compared with subjects with normal liver function (no CLD). Saxagliptin is the only DPP-4 inhibitor with an active metabolite (5-hydroxy-saxagliptin).

\begin{tabular}{|l|l|l|l|l|}
\hline & No CLD & Mild CLD & Moderate CLD & Severe CLD \\
& Mean (SD) & Mean (SD) & Mean (SD) & Mean (SD) \\
\hline $\begin{array}{l}\text { Sitagliptin } \\
\mathbf{1 0 0 ~} \mathbf{~ m g}^{[26]}\end{array}$ & $\mathrm{N}=10$ & or $(\% \mathrm{CV})^{*}$ & or $(\% \mathrm{CV})^{*}$ & or (\% CV)* \\
\hline $\begin{array}{l}\text { AUC } \\
\left(\mathrm{nmo} . .^{-1} . \mathrm{h}\right)\end{array}$ & $9500(2200)$ & - & $\mathrm{N}=10$ & - \\
\hline
\end{tabular}




\begin{tabular}{|c|c|c|c|c|}
\hline GMR $(90 \% \mathrm{CI})$ & & & $1.21(1.01-1.46)$ & \\
\hline $\begin{array}{l}\mathrm{C}_{\max } \\
\left(\mathrm{nmol.} \mathrm{l}^{-1}\right)\end{array}$ & $1046(286)$ & - & $1186(682)$ & - \\
\hline GMR $(90 \% \mathrm{CI})$ & & & $1.13(0.91-1.42)$ & \\
\hline $\begin{array}{l}\mathrm{T}_{\max } \\
\text { (h, median, SD) }\end{array}$ & $1.5(1.3)$ & - & $1.8(1.1)$ & - \\
\hline $\mathrm{T}_{1 / 2}(\mathrm{~h})$ & $13.9(2.0)$ & - & $14.4(3.9)$ & - \\
\hline $\begin{array}{l}\mathrm{CL}_{\mathrm{R}} \\
\left(\mathrm{ml} \cdot \mathrm{min}^{-1}\right)\end{array}$ & $282(84)$ & - & $243(98)$ & - \\
\hline $\begin{array}{l}\text { Vildagliptin } \\
100 \text { mg }^{[39]}\end{array}$ & $\mathrm{N}=6$ & $\mathrm{~N}=6$ & $\mathrm{~N}=6$ & $\mathrm{~N}=4$ \\
\hline $\begin{array}{l}\mathrm{AUC}_{\infty} \\
\left(\mathrm{ng} \cdot \mathrm{ml}^{-1} \cdot \mathrm{h}\right)\end{array}$ & $2580(425)$ & $2101(512)$ & $2437(742)$ & 3354 (1462) \\
\hline GMR $(90 \% \mathrm{CI})$ & & $0.80(0.60-1.06)$ & $0.92(0.69-1.23)$ & $1.22(0.89-1.68)$ \\
\hline $\begin{array}{l}\mathrm{C}_{\max } \\
\left(\text { ng. } \mathrm{ml}^{-1}\right)\end{array}$ & $675(263)$ & 497 (229) & $512(166)$ & $632(247)$ \\
\hline GMR $(90 \% \mathrm{CI})$ & & $0.70(0.46-1.05)$ & $0.77(0.51-1.17)$ & $0.94(0.59-1.49)$ \\
\hline $\begin{array}{l}\mathrm{T}_{\max } \\
(\mathrm{h}, \text { median, } \\
\text { range) }\end{array}$ & $1.3(1.0-3.0)$ & $1.2(1.0-2.0)$ & $1.0(0.5-3.0)$ & $2.0(1.0-4.0)$ \\
\hline $\mathrm{T}_{1 / 2}(\mathrm{~h})$ & $2.0(0.5)$ & $4.9(4.9)$ & $3.1(1.6)$ & $2.4(0.3)$ \\
\hline $\begin{array}{l}\mathrm{CL}_{\mathrm{R}} \\
\left(\mathrm{ml} \cdot \mathrm{min}^{-1}\right)\end{array}$ & $157(73)$ & $170(37)$ & $150(55)$ & $103(67)$ \\
\hline $\begin{array}{l}\text { Saxagliptin } \\
\mathbf{1 0} \mathbf{~ m g}^{[42,43]}\end{array}$ & $\mathrm{N}=8$ & $\mathrm{~N}=8$ & $\mathrm{~N}=8$ & $\mathrm{~N}=7$ \\
\hline
\end{tabular}




\begin{tabular}{|c|c|c|c|c|}
\hline $\begin{array}{l}\mathrm{AUC}_{\infty} \\
\left(\mathrm{ng} \cdot \mathrm{ml}^{-1} \cdot \mathrm{h}\right)\end{array}$ & $215(25)^{*}$ & $249(36)^{*}$ & $303(55)^{*}$ & $434(40)^{*}$ \\
\hline GMR $(90 \% \mathrm{CI})$ & & $\begin{array}{l}1.097 \\
(0.828-1.453)\end{array}$ & $\begin{array}{l}1.383 \\
(1.044-1.832)\end{array}$ & $\begin{array}{l}1.767 \\
(1.334-2.341)\end{array}$ \\
\hline $\begin{array}{l}\mathrm{C}_{\max } \\
\left(\mathrm{ng} \cdot \mathrm{ml}^{-1}\right)\end{array}$ & $54(25)^{*}$ & $75(26)^{*}$ & $58(36)^{*}$ & $72(38)^{*}$ \\
\hline GMR $(90 \% \mathrm{CI})$ & & $\begin{array}{l}1.077 \\
(0.763-1.519)\end{array}$ & $\begin{array}{l}1.016 \\
(0.720-1.432)\end{array}$ & $\begin{array}{l}0.941 \\
(0.667-1.328)\end{array}$ \\
\hline $\begin{array}{l}\mathrm{T}_{\max } \\
\text { (h, median, } \\
\text { range) }\end{array}$ & $0.63(0.5-1.5)$ & $0.88(0.25-1.50)$ & $1.50(0.5-5.0)$ & $1.0(0.5-1.0)$ \\
\hline $\mathrm{T}_{1 / 2}(\mathrm{~h})$ & $3.09(0.65)$ & $3.50(1.62)$ & $4.02(1.23)$ & $4.41(1.14)$ \\
\hline $\begin{array}{l}\mathrm{CL}_{\mathrm{R}} \\
\left(\mathrm{ml} \cdot \mathrm{min}^{-1}\right)\end{array}$ & $153(23)^{*}$ & $131(37)^{*}$ & $61(28)^{*}$ & $25(9)^{*}$ \\
\hline $\begin{array}{l}\text { 5-hydroxy- } \\
\text { saxagliptin }\end{array}$ & & & & \\
\hline $\begin{array}{l}\mathrm{AUC}_{\infty} \\
\left(\mathrm{ng} \cdot \mathrm{ml}^{-1} \cdot \mathrm{h}\right)\end{array}$ & $519(18)^{*}$ & $950(30)^{*}$ & $1660(50)^{*}$ & $2574(26)^{*}$ \\
\hline GMR $(90 \% \mathrm{CI})$ & & 0.78 (NA) & 0.93 (NA) & 0.67 (NA) \\
\hline $\begin{array}{l}\mathrm{C}_{\max } \\
\left(\text { ng. } \mathrm{ml}^{-1}\right)\end{array}$ & $92(32)^{*}$ & $129(26)^{*}$ & $135(35)^{*}$ & $131(34)^{*}$ \\
\hline GMR $(90 \% \mathrm{CI})$ & & 0.83 (NA) & 0.84 (NA) & 0.41 (NA) \\
\hline $\begin{array}{l}\mathrm{T}_{\max } \\
(\mathrm{h}, \text { median, } \\
\text { range) }\end{array}$ & $1.25(0.92-2.00)$ & $1.75(1.00-1.80)$ & $4.00(2.00-8.28)$ & $5.00(2.00-8.00)$ \\
\hline $\mathrm{T}_{1 / 2}(\mathrm{~h})$ & $3.85(0.56)$ & $5.83(2.72)$ & $8.55(2.44)$ & $9.88(1.28)$ \\
\hline
\end{tabular}




\begin{tabular}{|c|c|c|c|c|}
\hline $\begin{array}{l}\mathrm{CL}_{\mathrm{R}} \\
\left(\mathrm{ml} \cdot \mathrm{min}^{-1}\right)\end{array}$ & $76(11)^{*}$ & $52(17)^{*}$ & $28(13)^{*}$ & $12(3)^{*}$ \\
\hline $\begin{array}{l}\text { Linagliptin } \\
5 \mathbf{~ m g}^{[47]}\end{array}$ & $\mathrm{N}=8$ & $\mathrm{~N}=7$ & $\mathrm{~N}=9$ & $\mathrm{~N}=8$ \\
\hline $\begin{array}{l}\text { AUC }_{0-24 h} \\
\left(\mathrm{nmol.1}{ }^{-1} \cdot \mathrm{h}\right)\end{array}$ & $189(27.8)^{*}$ & $164(33.3)^{*}$ & $148(21.3)^{*}$ & $190(39.4)^{*}$ \\
\hline GMR $(90 \% \mathrm{CI})$ & & $\begin{array}{l}0.755 \\
(0.616-0.925)\end{array}$ & $\begin{array}{l}0.855 \\
(0.702-1.042)\end{array}$ & $\begin{array}{l}1.004 \\
(0.750-1.343)\end{array}$ \\
\hline $\begin{array}{l}\mathrm{C}_{\max } \\
\left(\mathrm{nmol}^{-1} \mathrm{l}^{-1}\right)\end{array}$ & $17.3(56.9)^{*}$ & $11.9(45.2)^{*}$ & $12.1(31.2)^{*}$ & $13.3(77.8)^{*}$ \\
\hline GMR $(90 \% \mathrm{CI})$ & & $\begin{array}{l}0.644 \\
(0.432-0.960)\end{array}$ & $\begin{array}{l}0.923 \\
(0.628-1.356)\end{array}$ & $\begin{array}{l}0.770 \\
(0.449-1.323)\end{array}$ \\
\hline $\begin{array}{l}\mathrm{T}_{\max } \\
\text { (h, median, } \\
\text { range) }\end{array}$ & $1.50(0.50-3.00)$ & $1.50(0.25-3.00)$ & $1.00(0.25-2.00)$ & $0.875(0.50-6.00)$ \\
\hline $\mathrm{T}_{1 / 2}(\mathrm{~h})$ & NA & NA & NA & NA \\
\hline $\begin{array}{l}\mathrm{CL}_{\mathrm{R} 0-24 \mathrm{~h}} \\
\left(\mathrm{ml} \cdot \mathrm{min}^{-1}\right)\end{array}$ & $12.2(123)^{*}$ & $7.31(215)^{*}$ & $5.75(145)^{*}$ & $8.74(161)^{*}$ \\
\hline $\begin{array}{l}\text { Alogliptin } \\
25 \mathrm{mg}^{[50]}[51]\end{array}$ & $\mathrm{N}=8$ & - & $\mathrm{N}=8$ & - \\
\hline $\begin{array}{l}\mathrm{AUC}_{\infty} \\
\left(\mathrm{ng} \cdot \mathrm{ml}^{-1} \cdot \mathrm{h}\right)\end{array}$ & $1607(23)^{*}$ & - & $1321(19)^{*}$ & - \\
\hline GMR $(90 \% \mathrm{CI})$ & & - & $\begin{array}{l}0.910 \\
(0.742-1.116)\end{array}$ & - \\
\hline $\begin{array}{l}\mathrm{C}_{\max } \\
\left(\text { ng. } \mathrm{ml}^{-1}\right)\end{array}$ & $140(28)^{*}$ & - & $110(38)^{*}$ & - \\
\hline GMR $(90 \% \mathrm{CI})$ & & - & $\begin{array}{l}0.923 \\
(0.683-1.249)\end{array}$ & - \\
\hline
\end{tabular}




\begin{tabular}{|c|c|c|c|c|}
\hline $\begin{array}{l}\mathrm{T}_{\max } \\
(\mathrm{h}, \text { median, } \\
\text { range) }\end{array}$ & $1.50(0.50-2.00)$ & - & $2.00(0.75-4.00)$ & - \\
\hline $\mathrm{T}_{1 / 2}(\mathrm{~h})$ & $18.3(12.2)^{*}$ & - & $20.7(16.1)^{*}$ & - \\
\hline $\begin{array}{l}\mathrm{CL}_{\mathrm{R} 0-24 \mathrm{~h}} \\
\left(\mathrm{ml} \cdot \mathrm{min}^{-1}\right)\end{array}$ & NA & - & $\mathrm{NA}$ & - \\
\hline
\end{tabular}

$\mathrm{AUC}_{\infty}$ : area under plasma concentration-time curve from zero to infinity. $\mathrm{AUC}_{0-24 \mathrm{~h}}$ : area under plasma concentration-time curve from zero to $24 \mathrm{~h}$. CI : Confidence interval. $\mathrm{CL}_{\mathrm{R}}$ : renal clearance. $\mathrm{C}_{\max }$ : maximum plasma concentration. $\mathrm{CV}$ : coefficient of variation. GMR : geometric mean ratio $\mathrm{CLD} /$ healthy subjects function. NA : not available. SD : standard deviation. $\mathrm{T}_{\max }$ : time to reach maximum concentration. $\mathrm{T} 1 / 2:$ terminal plasma half-life. 
Table 2 : Incidence of increased liver enzymes in two meta-analyses of randomized controlled trials ( $\geq 12->104$ weeks) with sitagliptin ${ }^{[34]}$, vildagliptin ${ }^{[40]}$ and linagliptin ${ }^{[48]}$.

\begin{tabular}{|c|c|c|c|}
\hline $\begin{array}{l}\text { Meta-analysis of } 25 \\
\text { trials }^{[34]}\end{array}$ & & $\begin{array}{l}\text { Sitagliptin } \\
100 \mathrm{mg} \\
\text { once daily }\end{array}$ & $\begin{array}{c}\text { Comparator } \\
\text { (placebo or } \\
\text { active) }\end{array}$ \\
\hline $\mathrm{AST} \geq 3 \times \mathrm{ULN}$ & & $\begin{array}{c}23 / 7726 \\
(0.3)\end{array}$ & $\begin{array}{c}21 / 6885 \\
(0.3)\end{array}$ \\
\hline $\mathrm{ALT} \geq 3 \times \mathrm{ULN}$ & & $\begin{array}{c}62 / 7726 \\
(0.8)\end{array}$ & $\begin{array}{c}41 / 6885 \\
(0.6)\end{array}$ \\
\hline $\begin{array}{l}\text { ALT or AST } \geq 3 x \\
\text { ULN }+ \text { bilirubin } \geq 2 \\
x \text { ULN }\end{array}$ & & $\begin{array}{l}1 / 7726 \\
(0.01)\end{array}$ & $\begin{array}{l}1 / 6885 \\
(0.01)\end{array}$ \\
\hline $\begin{array}{l}\text { Meta-analysis of } 38 \\
\text { trials }^{[40]}\end{array}$ & $\begin{array}{l}\text { Vildagliptin } \\
50 \text { mg once } \\
\text { daily }\end{array}$ & $\begin{array}{l}\text { Vildagliptin } \\
50 \text { mg twice } \\
\text { daily }\end{array}$ & $\begin{array}{c}\text { Comparator } \\
\text { (placebo/ } \\
\text { active) }\end{array}$ \\
\hline $\begin{array}{l}\text { ALT or AST } \geq 3 \times \\
\text { ULN }\end{array}$ & $\begin{array}{l}6 / 1406 \\
(0.43) \\
\end{array}$ & $\begin{array}{c}51 / 5874 \\
(0.87) \\
\end{array}$ & $\begin{array}{c}36 / 6171 \\
(0.58) \\
\end{array}$ \\
\hline $\begin{array}{l}\text { AST or AST } \geq 3 x \\
\text { ULN }+ \text { bilirubin } \geq 2 \\
x \text { ULN }\end{array}$ & 0/2085 (0) & $\begin{array}{l}3 / 5906 \\
(0.05)\end{array}$ & $\begin{array}{l}3 / 6595 \\
(0.04)\end{array}$ \\
\hline $\begin{array}{l}\text { ALT or AST } \geq 10 x \\
\text { ULN }\end{array}$ & 0/2091 (0) & $\begin{array}{l}1 / 5917 \\
(0.02)\end{array}$ & $\begin{array}{l}2 / 6695 \\
(0.03)\end{array}$ \\
\hline $\begin{array}{l}\text { Meta-analysis of } 8 \\
\text { trials }\end{array}$ & & $\begin{array}{l}\text { Linagliptin } \\
5 \text { mg once } \\
\text { daily }\end{array}$ & $\begin{array}{c}\text { Comparator } \\
\text { (placebo) }\end{array}$ \\
\hline $\begin{array}{l}\text { Hepatic enzyme } \\
\text { increase }\end{array}$ & & $3 / 2523(0.1)$ & $\begin{array}{l}1 / 1049 \\
(0.1)\end{array}$ \\
\hline
\end{tabular}

ALT : alanine aminotransferase AST : aspartate aminotransferase ULN : upper limit of the normal range 
Table 3 : Incidence of increased liver enzymes in SAVOR-TIMI $53^{[45]}$ with saxagliptin $5 \mathrm{mg}$ and in EXAMINE $^{[53]}$ with alogliptin.

\begin{tabular}{|c|c|c|c|}
\hline SAVOR TIMI $53^{[45]}$ & $\begin{array}{l}\text { Saxagliptin } \\
5 \mathrm{mg}\end{array}$ & Placebo & $\begin{array}{c}\mathrm{p} \\
\text { value }\end{array}$ \\
\hline & $(n=8280)$ & $(\mathrm{n}=8282)$ & \\
\hline Any liver abnormality* & $55(0.7)$ & $67(0.8)$ & 0.28 \\
\hline AST $>3 x$ ULN & $60(0.7)$ & $61(0.7)$ & 0.93 \\
\hline AST > 10X-x ULN & $12(0.1)$ & $15(0.2)$ & 0.57 \\
\hline $\begin{array}{l}\text { ALT or AST }>3 x \text { ULN } \\
+ \text { total bilirubin }>2 x \text { ULN }\end{array}$ & $13(0.2)$ & $23(0.3)$ & 0.097 \\
\hline EXAMINE $^{\lfloor 53\rfloor}$ & $\begin{array}{l}\text { Alogliptin } \\
25 \mathrm{mg} * *\end{array}$ & Placebo & $\begin{array}{c}\mathrm{p} \\
\text { value }\end{array}$ \\
\hline & $(n=2679)$ & $(n=2701)$ & \\
\hline ALT $>3 x$ ULN & $46(1.7)$ & $64(2.4)$ & 0.10 \\
\hline $\mathrm{AST}>3 \mathrm{x}$ ULN & $43(1.6)$ & $48(1.8)$ & 0.67 \\
\hline
\end{tabular}

* Patients may have had more than one type of event

** $12.5 \mathrm{mg}$ if renal impairment

ALT : alanine aminotransferase

AST : aspartate aminotransferase

ULN : upper limit of the normal range 
Table 4 : Steady-state non-compartmental PK parameters of linagliptin after multiple oral doses ( $5 \mathrm{mg}$ once daily for 7 days) in patients with mild or moderate chronic liver disease (CLD, according to Child-Pugh staging) compared with healthy subjects (adapted from ${ }^{[47]}$ ).

\begin{tabular}{|c|c|c|c|}
\hline & $\begin{array}{l}\text { Healthy } \\
\text { gMean (gCV) }\end{array}$ & $\begin{array}{l}\text { Mild CLD } \\
\text { gMean }(\mathrm{gCV})\end{array}$ & $\begin{array}{l}\text { Moderate CLD } \\
\text { gMean }(\mathrm{gCV})\end{array}$ \\
\hline Linagliptin 5 mg & $\mathrm{N}=8$ & $\mathrm{~N}=8$ & $\mathrm{~N}=8$ \\
\hline $\begin{array}{l}\text { AUC }_{\mathrm{t}, \mathrm{ss}} \\
\left(\mathrm{nmol} . \mathrm{l}^{-1} \cdot \mathrm{h}\right)\end{array}$ & $254(18.9)$ & $191(27.2)$ & $217(26.0)$ \\
\hline GMR $(90 \% \mathrm{CI})$ & & $\begin{array}{l}0.620 \\
(0.391-0.980)\end{array}$ & $\begin{array}{l}0.499 \\
(0.278-0.894)\end{array}$ \\
\hline $\mathrm{C}_{\max , \mathrm{ss}}\left(\mathrm{nmol} . \mathrm{I}^{-1}\right)$ & $20.8(38.6)$ & $13.4(55.8)$ & $19.2(52.5)$ \\
\hline GMR $(90 \% \mathrm{CI})$ & & $\begin{array}{l}0.507 \\
(0.253-1.017)\end{array}$ & $\begin{array}{l}0.530 \\
(0.266-1.053)\end{array}$ \\
\hline $\mathrm{T}_{\text {max,ss }}(\mathrm{h}$, median, range $)$ & $1.50(0.50-2.00)$ & $1.00(0.50-3.00)$ & $0.625(0.25-2.00)$ \\
\hline $\mathrm{T}_{1 / 2, \mathrm{ss}}(\mathrm{h})$ & $77.7(32.6)$ & $95.0(18.0)$ & $96.1(54.7)$ \\
\hline $\mathrm{CL}_{\mathrm{R}(0-24 \mathrm{~h}), \mathrm{ss}}\left(\mathrm{ml} \cdot \mathrm{min}^{-1}\right)$ & $49.5(40.8)$ & $44.7(40.1)$ & $49.8(50.8)$ \\
\hline $\begin{array}{l}\text { Accumulation ratio } \\
\left(\text { based on } \mathrm{AUC}_{0-24 \mathrm{~h}}\right)\end{array}$ & $1.34(22.2)$ & $1.25(23.9)$ & $1.46(28.4)$ \\
\hline $\begin{array}{l}\text { Accumulation ratio } \\
\text { (based on } \mathrm{C}_{\max } \text { ) }\end{array}$ & $1.20(53.9)$ & $1.22(64.3)$ & $1.53(65.8)$ \\
\hline
\end{tabular}

$\mathrm{AUC}_{\mathrm{t}, \mathrm{ss}}$ : area under plasma concentration-time curve at steady-state over the dosing interval $\mathrm{t}$. $\mathrm{AUC}_{0-24 \mathrm{~h}}$ : area under plasma concentration-time curve from zero to $24 \mathrm{~h}$. CI : confidence interval. $\mathrm{CL}_{\mathrm{R}(0-24 \mathrm{~h}), \mathrm{ss}}$ : renal clearance in the time interval 0 to $24 \mathrm{~h}$ at steady-state. $\mathrm{C}_{\mathrm{max}, \mathrm{ss}}$ : maximum plasma concentration at steady-state. $\mathrm{gCV}$ : geometric coefficient of variation. gMean : geometric mean. GMR : geometric mean ratio CLD/healthy subjects function. $\mathrm{T}_{\mathrm{max}, \mathrm{ss}}$ : time from last dosing to maximum plasma concentration at steady-state over the dosing 
interval t. $\mathrm{T}_{1 / 2, \mathrm{ss}}$ : terminal half-life in plasma at steady-state. 
Table 5 : Main PK parameters of liraglutide in subjects with various degrees of chronic liver disease (CLD) compared with subjects with normal liver function (no CLD) (adapted from reference $\left.{ }^{[57]}\right)$.

\begin{tabular}{|c|c|c|c|c|}
\hline Parameters & No CLD & $\begin{array}{l}\text { Mild CLD } \\
\text { Mean (SD) } \\
\text { GMR }(90 \% \mathrm{CI})\end{array}$ & $\begin{array}{l}\text { Moderate CLD } \\
\text { Mean (SD) } \\
\text { GMR }(90 \% \mathrm{CI})\end{array}$ & $\begin{array}{l}\text { Severe CLD } \\
\text { Mean (SD) } \\
\text { GMR }(90 \% \text { CI) }\end{array}$ \\
\hline $\begin{array}{l}\mathrm{AUC}_{\infty} \\
\left(\mathrm{pmol} \cdot \mathrm{l}^{-1} \cdot \mathrm{h}\right)\end{array}$ & $179641(43154)$ & $\begin{array}{l}149812(70007) \\
0.77(0.53-1.11)\end{array}$ & $\begin{array}{l}154615(47939) \\
0.87(0.60-1.25)\end{array}$ & $\begin{array}{l}105158(40843) \\
0.56(0.39-0.81)\end{array}$ \\
\hline 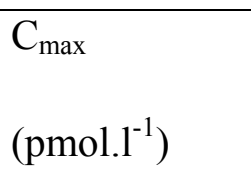 & $6746(1534)$ & $\begin{array}{l}6433(3859) \\
0.89(0.65-1.21)\end{array}$ & $\begin{array}{l}5593(1558) \\
0.80(0.59-1.09)\end{array}$ & $\begin{array}{l}4872(1637) \\
0.71(0.52-0.97)\end{array}$ \\
\hline $\mathrm{T}_{\max }(\mathrm{h})$ & $12.3(2.3)$ & $\begin{array}{l}11.3(3.8) \\
\text { NA }\end{array}$ & $\begin{array}{l}12.7(2.3) \\
\text { NA }\end{array}$ & $\begin{array}{l}13.2(2.9) \\
\text { NA }\end{array}$ \\
\hline $\mathrm{T}_{1 / 2}(\mathrm{~h})$ & $11.2(1.0)$ & $\begin{array}{l}10.7(1.1) \\
0.95(0.83-1.10)\end{array}$ & $\begin{array}{l}11.4(2.2) \\
1.01(0.88-1.17)\end{array}$ & $\begin{array}{l}9.5(1.0) \\
0.85(0.73-0.98)\end{array}$ \\
\hline $\mathrm{CL} / \mathrm{F}\left(1 . \mathrm{h}^{-1}\right)$ & $1.18(0.33)$ & $\begin{array}{l}1.55(0.59) \\
1.30(0.90-1.87)\end{array}$ & $\begin{array}{l}1.42(0.51) \\
1.15(0.80-1.66)\end{array}$ & $\begin{array}{l}2.21(0.99) \\
1.78(1.23-2.58)\end{array}$ \\
\hline $\mathrm{V}_{\mathrm{z} / \mathrm{F}}(1)$ & $18.7(3.8)$ & $\begin{array}{l}23.5(7.9) \\
1.23(0.86-1.77)\end{array}$ & $\begin{array}{l}23.1(8.2) \\
1.17(0.82-1.67)\end{array}$ & $\begin{array}{l}30.2(13.5) \\
1.51(1.05-2.17)\end{array}$ \\
\hline $\begin{array}{l}\text { Plasma } \\
\text { albumin } \\
\text { concentration } \\
\left(\mathrm{g} . \mathrm{l}^{-1}\right)\end{array}$ & $38.2(2.7)$ & $\begin{array}{l}37.2(2.6) \\
\text { NA }\end{array}$ & $\begin{array}{l}35.3(4.3) \\
\text { NA }\end{array}$ & $\begin{array}{l}27.8(4.4) \\
\text { NA }\end{array}$ \\
\hline $\begin{array}{l}\text { Unbound } \\
\text { fraction of } \\
\text { liraglutide }\end{array}$ & $0.53(0.46)$ & $\begin{array}{l}0.59(0.61) \\
\text { NA }\end{array}$ & $\begin{array}{l}0.68(0.45) \\
\text { NA }\end{array}$ & $\begin{array}{l}0.40(0.20) \\
\text { NA }\end{array}$ \\
\hline
\end{tabular}




\begin{tabular}{|l|l|l|l|l|}
\hline$(\%)(*)$ & & & & \\
\hline
\end{tabular}

$\mathrm{AUC}_{\infty}$ : area under the liraglutide plasma concentration-time curve from zero to infinity. $\mathrm{CI}$ : Confidence interval. $\mathrm{CL} / \mathrm{F}$ : total apparent clearance. $\mathrm{C}_{\max }$ : maximum liraglutide plasma concentration. GMR : geometric mean ratio CLD/healthy subjects function. NA : not available. SD : standard deviation. Tmax : time to reach maximum liraglutide concentration. $\mathrm{T} 1 / 2$ : terminal plasma half-life. Vz/F : apparent volume of distribution.

$\left(^{*}\right)$ : at a liraglutide concentration of 1000 pmol. $^{-1}$ (the between-group differences were even greater at a higher liragutide concentration of $100000 \mathrm{pmol}^{-1} \mathrm{l}^{-1}$ ). 


\section{References}

1. Picardi A, D'Avola D, Gentilucci UV, et al. Diabetes in chronic liver disease: from old concepts to new evidence. Diabetes Metab Res Rev 2006 Jul-Aug; 22 (4):274-83.

2. Loria P, Lonardo A, Anania F. Liver and diabetes. A vicious circle. Hepatol Res 2013 Jan; 43 (1):51-64.

3. Byrne CD. Dorothy Hodgkin Lecture 2012: non-alcoholic fatty liver disease, insulin resistance and ectopic fat: a new problem in diabetes management. Diabet Med 2012 Sep; 29 (9):1098-107.

4. Hsieh PS, Hsieh YJ. Impact of liver diseases on the development of type 2 diabetes mellitus. World J Gastroenterol 2011 Dec 28; 17 (48):5240-5.

5. Garcia-Compean D, Jaquez-Quintana JO, Maldonado-Garza H. Hepatogenous diabetes. Current views of an ancient problem. Ann Hepatol 2009 Jan-Mar; 8 (1):13-20.

6. Petrides AS, DeFronzo RA. Glucose and insulin metabolism in cirrhosis. J Hepatol 1989 Jan; 8 (1):107-14.

7. Petrides AS, Vogt C, Schulze-Berge D, et al. Pathogenesis of glucose intolerance and diabetes mellitus in cirrhosis. Hepatology 1994 Mar; 19 (3):616-27.

8. Mazza A, Fruci B, Garinis GA, et al. The role of metformin in the management of NAFLD. Exp Diabetes Res 2012 2012:716404.

9. Fruci B, Giuliano S, Mazza A, et al. Nonalcoholic Fatty liver: a possible new target for type 2 diabetes prevention and treatment. Int J Mol Sci 201314 (11):22933-66.

10. Scheen AJ. Pharmacokinetic and toxicological considerations for the treatment of diabetes in patients with liver disease. Expert Opin Drug Metab Toxicol 2014 Jun;10(6):83957

11. Khan R, Foster GR, Chowdhury TA. Managing diabetes in patients with chronic liver disease. Postgrad Med 2012 Jul; 124 (4):130-7.

12. Tolman KG, Fonseca V, Dalpiaz A, et al. Spectrum of liver disease in type 2 diabetes and management of patients with diabetes and liver disease. Diabetes Care 2007 Mar; 30

(3):734-43.

13. Olaywi M, Bhatia T, Anand S, et al. Novel anti-diabetic agents in non-alcoholic fatty liver disease: a mini-review. Hepatobiliary Pancreat Dis Int 2013 Dec; 12 (6):584-8.

14. Giorda CB, Nada E, Tartaglino B. Pharmacokinetics, safety, and efficacy of DPP-4 inhibitors and GLP-1 receptor agonists in patients with type 2 diabetes mellitus and renal or hepatic impairment. A systematic review of the literature. Endocrine 2014 Feb 8;Epub 2014/02/11.

15. Drucker DJ, Nauck MA. The incretin system: glucagon-like peptide-1 receptor agonists and dipeptidyl peptidase-4 inhibitors in type 2 diabetes. Lancet 2006 Nov 11; 368 (9548):1696-705.

16. Scheen AJ. A review of gliptins in 2011. Expert Opin Pharmacother 2012 Jan; 13 (1):81-99.

17. Owens DR, Monnier L, Bolli GB. Differential effects of GLP-1 receptor agonists on components of dysglycaemia in individuals with type 2 diabetes mellitus. Diabetes Metab 2013 Dec; 39(6):485-96.

18. Meier JJ. GLP-1 receptor agonists for individualized treatment of type 2 diabetes mellitus. Nat Rev Endocrinol 2012 Dec; 8 (12):728-42.

19. Blaslov K, Bulum T, Zibar K, et al. Incretin based therapies: A novel treatment approach for non-alcoholic fatty liver disease. World J Gastroenterol 2014 Jun 21; 20 (23):7356-65.

20. Verbeeck RK. Pharmacokinetics and dosage adjustment in patients with hepatic dysfunction. Eur J Clin Pharmacol 2008 Dec; 64 (12):1147-61. 
21. Srivastava B, Alexander GJ. Renal failure in chronic liver disease and the hepatorenal syndrome. Br J Hosp Med (Lond) 2011 Sep; 72 (9):497-503.

22. Scheen AJ. Pharmacokinetic considerations for the treatment of diabetes in patients with chronic kidney disease. Expert Opin Drug Metab Toxicol 2013 May; 9 (5):529-50.

23. Scheen AJ. Pharmacokinetics of dipeptidylpeptidase-4 inhibitors. Diabetes Obes Metab 2010 Aug; 12 (8):648-58.

24. Golightly LK, Drayna CC, McDermott MT. Comparative clinical pharmacokinetics of dipeptidyl peptidase-4 inhibitors. Clin Pharmacokinet 2012 Jun 11; 51 (8):501-14.

25. Vincent SH, Reed JR, Bergman AJ, et al. Metabolism and excretion of the dipeptidyl peptidase 4 inhibitor [14C] sitagliptin in humans. Drug Metab Dispos 2007 Apr; 35 (4):533-8. 26. Migoya EM, Stevens CH, Bergman AJ, et al. Effect of moderate hepatic insufficiency on the pharmacokinetics of sitagliptin. Can J Clin Pharmacol 2009 Winter; 16 (1):e165-70.

27. Arase Y, Kawamura Y, Seko Y, et al. Efficacy and safety in sitagliptin therapy for diabetes complicated by non-alcoholic fatty liver disease. Hepatol Res 2013 Nov; 43(11):1163-8

28. Iwasaki T, Yoneda M, Inamori M, et al. Sitagliptin as a novel treatment agent for nonalcoholic Fatty liver disease patients with type 2 diabetes mellitus. Hepatogastroenterology 2011 Nov-Dec; 58 (112):2103-5.

29. Itou M, Kawaguchi T, Taniguchi E, et al. Dipeptidyl Peptidase IV inhibitor improves insulin resistance and steatosis in a refractory nonalcoholic fatty liver disease patient: a case report. Case Rep Gastroenterol 2012 May; 6 (2):538-44.

30. Fukuhara T, Hyogo H, Ochi H, et al. Efficacy and safety of sitagliptin for the treatment of nonalcoholic fatty liver disease with type 2 diabetes mellitus.

Hepatogastroenterology 2014 Mar-Apr; 61 (130):323-8.

31. Yilmaz Y, Yonal O, Deyneli O, et al. Effects of sitagliptin in diabetic patients with nonalcoholic steatohepatitis. Acta Gastroenterol Belg 2012 Jun; 75 (2):240-4.

32. Arase Y, Suzuki F, Kobayashi M, et al. Efficacy and safety in sitagliptin therapy for diabetes complicated by chronic liver disease caused by hepatitis C virus. Hepatol Res 2011 Jun; 41 (6):524-9.

33. Iwasaki T, Tomeno W, Yoneda M, et al. Non-alcoholic fatty liver disease adversely affects the glycemic control afforded by sitagliptin. Hepatogastroenterology 2012 Jul-Aug; 59 (117):1522-5.

34. Gooßen K, Gräber S. Longer term safety of dipeptidyl peptidase-4 inhibitors in patients with type 2 diabetes mellitus: systematic review and meta-analysis. Diabetes Obes Metab 2012 Dec;14(12):1061-72.

35. Toyoda-Akui M, Yokomori H, Kaneko F, et al. A case of drug-induced hepatic injury associated with sitagliptin. Intern Med 201150 (9):1015-20.

36. Gross BN, Cross LB, Foard J, et al. Elevated hepatic enzymes potentially associated with sitagliptin. Ann Pharmacother 2010 Feb; 44 (2):394-5.

37. Navarro VJ, Senior JR. Drug-related hepatotoxicity. N Engl J Med 2006 Feb 16; 354 (7):731-9.

38. He YL. Clinical pharmacokinetics and pharmacodynamics of vildagliptin. Clin Pharmacokinet 2012 Mar 1; 51 (3):147-62.

39. He YL, Sabo R, Campestrini J, et al. The influence of hepatic impairment on the pharmacokinetics of the dipeptidyl peptidase IV (DPP-4) inhibitor vildagliptin. Eur J Clin Pharmacol 2007 Jul; 63 (7):677-86.

40. Ligueros-Saylan M, Foley JE, Schweizer A, et al. An assessment of adverse effects of vildagliptin versus comparators on the liver, the pancreas, the immune system, the skin and in patients with impaired renal function from a large pooled database of Phase II and III clinical trials. Diabetes Obes Metab 2010 Jun; 12 (6):495-509. 
41. Schweizer A, Dejager S, Foley JE, et al. Assessing the general safety and tolerability of vildagliptin: value of pooled analyses from a large safety database versus evaluation of individual studies. Vasc Health Risk Manag 2011 7:49-57.

42. Patel C, Castaneda L, Frevert U, et al. Single-dose pharmacokinetics and safety of saxagliptin in subjects with hepatic impairment compared with healthy subjects. Diabetes 200857 (Suppl 1):A160, Abstract 537-P.

43. Boulton DW, Li L, Frevert EU, et al. Influence of renal or hepatic impairment on the pharmacokinetics of saxagliptin. Clin Pharmacokinet 2011 Apr 1; 50 (4):253-65.

44. Ali S, Fonseca V. Saxagliptin overview: special focus on safety and adverse effects. Expert Opin Drug Saf 2013 Jan; 12 (1):103-9.

45. Scirica BM, Bhatt DL, Braunwald E, et al. Saxagliptin and cardiovascular outcomes in patients with type 2 diabetes mellitus. N Engl J Med 2013 Oct 3; 369 (14):1317-26.

46. Scheen AJ. Linagliptin for the treatment of type 2 diabetes (pharmacokinetic evaluation). Expert Opin Drug Metab Toxicol 2011 Dec; 7 (12):1561-76.

47. Graefe-Mody U, Rose P, Retlich S, et al. Pharmacokinetics of linagliptin in subjects with hepatic impairment. Br J Clin Pharmacol 2012 Jul; 74 (1):75-85.

48. Schernthaner G, Barnett AH, Emser A, et al. Safety and tolerability of linagliptin: a pooled analysis of data from randomized controlled trials in 3572 patients with type 2 diabetes mellitus. Diabetes Obes Metab 2012 May; 14 (5):470-8.

49. Kutoh E. Probable linagliptin-induced liver toxicity: A case report. Diabetes Metab 2014 Feb; 40 (1):82-4.

50. Karim A, Fleck P, Dorsey D, et al. Single dose pharmacokinetics of alogliptin benzoate(SYR-322) in subjects with moderate hepatic impairment J Clin Pharmacol 200747 (9):1207 (abstract 107).

51. Food and Drug Administration, Center for Drug Evaluation and Research. Clinical Pharmacology and Biopharmeutics Reviews : Application number : 022271Orig1s000 (Nesina, alogliptin).

http://wwwaccessdatafdagov/drugsatfda_docs/nda/2013/022271Orig1s000ClinPharmRpdf 2013 (accessed April 10, 2014).

52. Scott LJ. Alogliptin: a review of its use in the management of type 2 diabetes mellitus. Drugs 2010 Oct 22; 70 (15):2051-72.

53. White WB, Cannon CP, Heller SR, et al. Alogliptin after acute coronary syndrome in patients with type 2 diabetes. N Engl J Med 2013 Oct 3; 369 (14):1327-35.

54. Kajiwara A, Saruwatari J, Sakata M, et al. Risk factors for adverse symptoms during dipeptidyl peptidase-IV inhibitor therapy: a questionnaire-based study carried out by the Japan Pharmaceutical Association Drug Event Monitoring project in Kumamoto Prefecture. Drug Saf 2013 Oct; 36 (10):981-7.

55. Inzucchi SE, Bergenstal RM, Buse JB, et al. Management of hyperglycaemia in type 2 diabetes: a patient-centered approach. Position statement of the American Diabetes Association (ADA) and the European Association for the Study of Diabetes (EASD).

Diabetologia 2012 Jun; 55 (6):1577-96.

56. Jespersen MJ, Knop FK, Christensen M. GLP-1 agonists for type 2 diabetes: pharmacokinetic and toxicological considerations. Expert Opin Drug Metab Toxicol 2013 Jan; 9 (1):17-29.

57. Flint A, Nazzal K, Jagielski P, et al. Influence of hepatic impairment on pharmacokinetics of the human GLP-1 analogue, liraglutide. Br J Clin Pharmacol 2010 Dec; 70 (6):807-14.

58. Copley K, McCowen K, Hiles R, et al. Investigation of exenatide elimination and its in vivo and in vitro degradation. Curr Drug Metab 2006 May; 7 (4):367-74. 
59. Fan $\mathrm{H}, \mathrm{Pan} \mathrm{Q}, \mathrm{Xu} \mathrm{Y}$, et al. Exenatide improves type 2 diabetes concomitant with nonalcoholic fatty liver disease. Arq Bras Endocrinol Metabol 2013 Dec; 57 (9):702-8.

60. Cuthbertson DJ, Irwin A, Gardner CJ, et al. Improved glycaemia correlates with liver fat reduction in obese, type 2 diabetes, patients given glucagon-like peptide-1 (GLP-1) receptor agonists. PLoS One 20127 (12):e50117.

61. Shao N, Kuang HY, Hao M, et al. Effects of exenatide on obesity and NAFLD with elevated liver enzymes in patients with type 2 diabetes. Diabetes Metab Res Rev 2014 May 13;Epub 2014/05/16.

62. Kenny PR, Brady DE, Torres DM, et al. Exenatide in the treatment of diabetic patients with non-alcoholic steatohepatitis: a case series. Am J Gastroenterol 2010 Dec; 105 (12):2707-9.

63. Xu F, Li Z, Zheng X, et al. SIRT1 mediates the effect of GLP-1 receptor agonist exenatide on ameliorating hepatic steatosis. Diabetes 2014 Jun 19;Epub 2014/06/21.

64. Buse JB, Klonoff DC, Nielsen LL, et al. Metabolic effects of two years of exenatide treatment on diabetes, obesity, and hepatic biomarkers in patients with type 2 diabetes: an interim analysis of data from the open-label, uncontrolled extension of three double-blind, placebo-controlled trials. Clin Ther 2007 Jan; 29 (1):139-53.

65. Malm-Erjefalt M, Bjornsdottir I, Vanggaard J, et al. Metabolism and excretion of the once-daily human glucagon-like peptide-1 analog liraglutide in healthy male subjects and its in vitro degradation by dipeptidyl peptidase IV and neutral endopeptidase. Drug Metab Dispos 2010 Nov; 38 (11):1944-53.

66. Armstrong MJ, Houlihan DD, Rowe IA, et al. Safety and efficacy of liraglutide in patients with type 2 diabetes and elevated liver enzymes: individual patient data meta-analysis of the LEAD program. Aliment Pharmacol Ther 2013 Jan; 37 (2):234-42.

67. Ohki $\mathrm{T}$, Isogawa A, Iwamoto $\mathrm{M}$, et al. The effectiveness of liraglutide in nonalcoholic fatty liver disease patients with type 2 diabetes mellitus compared to sitagliptin and pioglitazone. TheScientificWorldJournal 2012 2012:496453.

68. Kahal H, Abouda G, Rigby AS, et al. Glucagon-like peptide-1 analogue, liraglutide, improves liver fibrosis markers in obese women with polycystic ovary syndrome and nonalcoholic fatty liver disease. Clin Endocrinol (Oxf) 2013 Nov 21;Epub 2013/11/22.

69. D'Amico E. Efficacy of liraglutide in a patient with type 2 diabetes and cryptogenic cirrhosis. Acta Biomed 2011 Aug; 82 (2):160-1.

70. Eguchi Y, Kitajima Y, Hyogo H, et al. Pilot study of liraglutide effects in nonalcoholic steatohepatitis and non-alcoholic fatty liver disease with glucose intolerance in Japanese patients (LEAN-J). Hepatol Res 2014 May 4;Epub 2014/05/07.

71. Kern E, VanWagner LB, Yang GY, et al. Liraglutide-induced autoimmune hepatitis. JAMA Intern Med 2014 Jun 1; 174 (6):984-7.

72. Forst T, Pfutzner A. Pharmacological profile, efficacy and safety of lixisenatide in type 2 diabetes mellitus. Expert Opin Pharmacother 2013 Nov; 14 (16):2281-96.

73. European Medicines Agency. Assessment report : Lyxumia (lixisenatide). wwwemaeuropaeu//EPARassessment_report// 2012 (accessed April 10, 2014).

74. Balaban YH, Korkusuz P, Simsek H, et al. Dipeptidyl peptidase IV (DDP IV) in NASH patients. Annals of hepatology 2007 Oct-Dec; 6 (4):242-50.

75. Itou M, Kawaguchi T, Taniguchi E, et al. Dipeptidyl peptidase-4: a key player in chronic liver disease. World J Gastroenterol 2013 Apr 21; 19 (15):2298-306.

76. Armstrong MJ, Barton D, Gaunt P, et al. Liraglutide efficacy and action in nonalcoholic steatohepatitis (LEAN): study protocol for a phase II multicentre, double-blinded, randomised, controlled trial. BMJ open 20133 (11):e003995. 
77. Bernsmeier C, Meyer-Gerspach AC, Blaser LS, et al. Glucose-induced glucagon-like Peptide 1 secretion is deficient in patients with non-alcoholic fatty liver disease. PLoS One 20149 (1):e87488.

78. Muscelli E, Mari A, Casolaro A, et al. Separate impact of obesity and glucose tolerance on the incretin effect in normal subjects and type 2 diabetic patients. Diabetes 2008 May; 57 (5):1340-8. 